\title{
Optimization of Fruit Garbage Enzymes Requirements for Biocatalytic Remediation of Used Motor Oil-Contaminated Soil
}

\author{
Indo Sabo Bulai ${ }^{\oplus} \cdot$ Haruna Adamu $^{\dagger} \oplus \cdot$ Yuguda Abubakar Umar $^{\oplus} \cdot$ Ahmed Sabo $^{\oplus}$
}

Department of Environmental Management Technology, Abubakar Tafawa Balewa University

(Received March 3, 2021; Revised April 6, 2021; Accepted April 8, 2021)

Objectives: In this research work, we investigated the biocatalytic potency of orange and watermelon garbage enzymes in the remediation of used motor oil-contaminated soils. The optimization of the biocatalytic remediation process was evaluated through D-optimal of response surface methodology (RSM) design of design expert.

Methods: The optimization of the biocatalytic process was evaluated with D-optimal model of response surface methodology (RSM) design, where input variables in the system were garbage enzymes solutions of orange and watermelon peels (biocatalysts) and two different pollution levels. The two levels of pollution factor considered were 5 and $10 \%(\mathrm{w} / \mathrm{w})$ oil pollution levels and used as independent variables; while the response of the system was in oil and grease $(\mathrm{O} \& \mathrm{G})$ removal as dependent variables that were monitored under 6-week remediation process.

Results and Discussion: The result indicated that the model was highly significant and good predictors of the response fate of oil and grease $(\mathrm{O} \& \mathrm{G})$ removal by the orange and watermelon garbage enzymes, as indicated by their coefficients of determination: $\mathrm{R}^{2}=0.90627$ and $\mathrm{R}^{2}=0.88365$ at $\mathrm{p}<0.05$, respectively. Therefore, it was observed from the numerical optimization carried out that 54.2 and $53.8 \%$ O\&G removal was achieved with orange garbage enzymes at 5 and $10 \%$ pollution level respectively after six weeks. On the other hand, 54.7 and $55.2 \%$ O\&G removal was accomplished with the same pollution level respectively under the influence of watermelon garbage enzymes after six weeks of the remediation process.

Conclusion: In response to what was achieved in this research work, the enzymes produced from the orange and watermelon garbage removed oil in terms of $O \& G$ from used motor oil-contaminated soils biocatalytically and hence could be applied in the remediation of oil contaminated soils.

Keywords: Oil-Contaminated Soil, Used Motor-Oil, Remediation and Biocatalyst 


\section{Introduction}

The indiscriminate and unstructured establishment of automobile vehicle repair services stations has been a common practice in urban areas, particularly in developing countries. This often hosts and blow-up myriads of environmental problems in the absence of any strategy targeted at minimizing the pollution from the source point such as automobile engine service stations. The handling procedure of used motor-oils used in internal combustion engines is one of such environmental concerns in sub-Saharan African countries. In Nigeria, it has been estimated that over 76 million litres of used motor-oils is drained annually due to mechanical service of automobile and generator engines in mechanic workshops excluding those spilled accidentally from engine exhaust systems during engine operations. ${ }^{1,2)}$ In the mechanic workshop, the used motor-oil is often carelessly drained as waste oils unto and into the soil and water environments respectively by auto-mechanics during servicing of engine for operational management. $^{3,4)}$ The unfortunate part of such reckless discard of oils in the mechanic workshops is habitually left upon soil untreated with disregard of observation of environmental protection-right protocols over years, which such continuous neglect has led to accumulation of the oil and is of high environmental concern. ${ }^{5)}$ This practice is persistently occurring simply because soil has been considered as one of the major sinks upon which both solid and liquid wastes are dumped into the ecosystem regardless of its potential to constitute environmental pollution. Unknowingly, most of the people working in the mechanic workshops are not aware that the severity of soil pollution problem caused by oil does not stop at the soil surface environment alone, it percolates and reaches groundwater due to continuous and uncontrollable disposal of used motor-oil. ${ }^{6}$ In addition, absence of effective waste management strategies due to weak nature of regulations and monitoring at the points of generation of waste in most of the sub-Saharan African countries exacerbates the situation and therefore, such pollution problem persists and as a result now attracts public attention. The problem of such pollution doesn't stop with the oil alone, but as the discharged used motor-oil contains weary metals from automobile engines serves as a source of toxic metals along with other hazardous hydrocarbons that could contribute and exacerbate chronic hazards including cells and tissues defects. ${ }^{5,7,8)}$ Therefore, as the quality of life on earth is inextricably linked to the overall quality of the environment, an essential and appropriate remediation method to deal with the used motor oil-contaminated soil that commonly occurs is fervently required for managing, preserving, and restoring the quality of soil environment.

Although, a number of physical and chemical remediation technologies have been developed for removing toxic contaminants of petroleum origin from contaminated soil with aim of enhancing soil health such as aeration. ${ }^{9)}$ However, these technologies are disadvantaged by several limitations such as high cost of operation and most importantly their environmental unfriendliness, as they tend to destroy soil texture and other characteristics, and at best, they can only temporarily neutralize the priority pollutants without essentially removing the pollutants from the soil host. ${ }^{10)}$ In that case, bioremediation clean-up techniques have been advocated for the removal of hydrocarbon-based soil contamination in recent times. Simply, it is widely considered safe, environmentally compatible and friendly as well as relatively cheaper when compared to conventional physical and chemical remediation techniques. ${ }^{5,11-13)}$ Despite the advantage of bioremediation over the physical and chemical methods in removing water and soil pollutants, the method has been limited by nutrients requirement for bolstering the microbes for the breakdown of the contaminants and also, the reactions take years to produce desired and substantial results, respectively. ${ }^{14)}$ Besides, bioremediation goes with its many inherent difficulties, such as maintaining the microbial population necessary to degrade a certain compound, and the necessary growth conditions (i.e., proper temperature, oxygen availability or limitation, moisture levels, pollutant levels, and $\mathrm{pH}$ ) required by the microbes. ${ }^{15)}$ In spite of this associated deficiencies in the bioremediation method, more efforts need to be focused towards harnessing modern-day bioremediation process as a suitable alternative.

In the quest of suitable alternatives, it has been reported that microbial extracellular-based enzymes play important role in the decontamination processes of water and soil polluted environments. ${ }^{16)}$ For example, the microbial hydrolytic enzymes have been found promising in reducing the organic compounds, removal of pathogenic organisms, and odour in waste sludge. ${ }^{17,18)}$ However, much enough has not been done in the use of enzymes for pollution management, as researchers till now used commercial hydrolytic enzymes for pollutant degradation and stabilization that is not economical. ${ }^{19)}$ Therefore, there is a need to find an alternative cheap source of abundance of such enzymes, as they could serve as powerful tools to preserve the environment. ${ }^{20)}$ It is 
known that enzymes are generally produced from animals, plants, or microbes. To this end, enzymes from plant sources are relatively cheaper and have easier extraction and

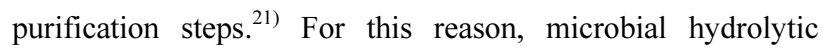
enzymes, which are readily available can be sourced from plant-based wastes.

In search of cheapest source of hydrolytic enzymes, decomposable plant wastes commonly thrown into the environment can be made resourceful stuff for production of value-added bio-product that could contain mixture of such enzymes. A value-added bio-product was developed from fruits and vegetables organic solid wastes in the year 2006 by a researcher from Thailand and named the extract solution obtained as garbage enzymes. ${ }^{22)}$ From the analysis conducted, this enzyme is a complex organic substance of protein chains, organic acids, and mineral salts produced easily by simple fermentation of fruit and vegetable wastes in water mixed with brown sugar or molasses sugar. ${ }^{23)}$ The organic solution harvested after the fermentation is a crude enzyme solution, containing different extracellular enzymes. Extracellular enzymes refer to those enzymes that are secreted by microbes that enter the aqueous phase during an aerobic submerged fermentation process. $^{24)}$ It is reported that the classes of extracellular enzymes such as proteases, amylases, and lipases are produced and harvested during aerobic fermentation of organic matter. ${ }^{25)}$ Consequently, the garbage enzyme functions in a similar way to enzymes in achieving a high degree of degradation within a short time.

However, knowing that enzymatic remediation is a multifactor dependent, carrying out such remediation process at its optimum is of great importance. This is because enzymes activity can be affected by a variety of factors, such as temperature, $\mathrm{pH}$, and concentration of both enzyme and substrate. Therefore, enzymes work best within the limits of specific temperature, $\mathrm{pH}$, and concentrations, and sub-optimal conditions can cause enzymes to lose their ability to bind to substrates. In most accustomed-research practices, the efficiency of a multivariable dependent process is studied by varying one factor at a time while other factors are kept constant. Such practice could be counterproductive to biocatalytic remediation objective. In addition, this method normally ignores the interactions occurring among the factors. Thus, it may not give the best conditions that give the optimum efficiency of the process under investigation and therefore, soil contaminants to persist. ${ }^{26)}$ In response to such limitations, Response Surface Methodology (RSM) has been discovered as an effective statistical method of optimizing a system process. Upon application of this method of optimization, apart from revealing the true optimum conditions with a minimal number of experiments compared to the conventional method, it presents the mathematical model(s) defining the relationships between the response(s) and the factors. $^{27)}$

Recently, RSM has been successfully used to optimize many processes including bio-remediation system. ${ }^{28-30)}$ Therefore, this study used the D-optimal design of RSM to investigate the effect of numeric (concentrations of fruit garbage enzymes) and categorical factors (pollution levels) on the biocatalytic remediation of soil that was artificially contaminated with used motor-oil. Accordingly, the variables of the system were biocatalysts (variable concentrations of orange and watermelon garbage enzymes) and pollution level that was of two categories, viz., lower level (5\%), and higher level (10\%). The response was the oil and grease percentage removal, which was employed to predict the fate of oil contamination in soils when subjected to biocatalytic remediation approach using orange and watermelon garbage enzymes extract solutions.

\section{Materials and methods}

\subsection{Soil samples and used motor-oil}

The soil samples were collected from uncontaminated field located within the coordinates of $10^{\circ} 16^{\prime} 34^{\prime \prime} \mathrm{N}$ and $9^{\circ} 47^{\prime}$ 24 "E, which was free from any form of hydrocarbon-based oil contamination. Samples were homogenised, air-dried, and sieved to $2 \mathrm{~mm}$, and stored at room temperature before the experiment. $^{31)}$

\subsection{Soil physico-chemical analysis}

Soil $\mathrm{pH}$ was determined according to Agarry and Oghenejoboh $^{32)}$, where $50 \mathrm{~g}$ of soil was placed into a beaker and mixed with $50 \mathrm{~cm}^{3}$ of distilled water. The mixture was stirred with a glass rod for some time, followed by insertion of calibrated $\mathrm{pH}$ meter into the mixture. The meter was left submerged until reading was stabilized and finally recorded. Total Organic Carbon (TOC) was determined based on the procedure described by Walkley and Black ${ }^{33)}$, in which $0.2 \mathrm{~g}$ of sieved soil sample was mixed with $1 \mathrm{~N}$ of $\mathrm{K}_{2} \mathrm{CrO}_{7}$ and $20 \mathrm{~cm}^{3}$ of concentrated $\mathrm{H}_{2} \mathrm{SO}_{4}$ and heated until the temperature reached $135^{\circ} \mathrm{C}$. After cooling, the mixture was diluted to 200 $\mathrm{cm}^{3}$ and 3-4 drops of Ferroin indicator was added and titrated with $0.4 \mathrm{~N}$ of $\mathrm{FeSO}_{4}$. Two blank samples were prepared 
without soil in the same way. The titer values of $\mathrm{FeSO}_{4}$ consumed in the sample titration and in the blank were used to quantify the percentage of organic carbon of the soil. The moisture content of the soil was measured using protocols reported in the literature ${ }^{34)}$. In the procedure, weight of empty aluminum moisture box was recorded and $100 \mathrm{~g}$ of soil sample was added onto it and the weight was also recorded before the soil was oven dried at temperature between 105 and $110^{\circ} \mathrm{C}$ for 24 hrs. The loss of weight was determined after it was cold in desiccator and considered the moisture contained in the soil sample. The contents of oil and grease were determined based on the standard test method approved by the Department of Sustainable Natural Resources Soil Survey. ${ }^{35)}$ The nitrate-nitrogen $\left(\mathrm{NO}_{3}-\mathrm{N}\right)$ content was calorimetrically determined using Colorimeter (DR/890) based on the method described by $\mathrm{HACH}$ using NitraVer 5 reagent.

\subsubsection{Soil microbial analysis}

The determination of total colony count was done using the spread plate technique ${ }^{36}$ ) using nutrient agar (Oxide). Incubation of the plate was done at $35^{\circ} \mathrm{C}$ for $18-24 \mathrm{hrs} .^{32,37)}$ The spread plate technique was conducted by the method reported in the literature ${ }^{38)}$, while the number of colonies in colony-forming units per gram of soil (cfu/g) was calculated as worked out by Onuoha et al. ${ }^{39)}$ The microbial load in the soil samples was determined before and after the soil amendment with used motor-oil.

\subsection{Production and characterization of enzymes from fruit garbage}

The production of garbage enzymes from peel wastes of sweet orange (Citrus sinensis (L.) Osbeck) and watermelon (Citrullus lanatus (Thunb.) were separately done. Deionised water was used throughout and brown sugar was used as the carbon source for the microbes in the mixture of fruit wastes and water. The fruit peels of orange and watermelon were cut into pieces. Each of the fruit peels was mixed with brown sugar solution and deionized water in a ratio of $3: 1: 10(\mathrm{v} / \mathrm{w})$ in a plastic container separately and allowed to ferment. The containers were kept in a cool, dry, and well-ventilated area for complete degradation of organic matter for three months. ${ }^{23)}$ After the 3-month fermentation process, the solutions of the fruit wastes were filtered and labelled appropriately as the extract solutions of fruit garbage enzymes of orange and watermelon peel wastes. The enzyme solutions were characterized for $\mathrm{pH}$, total solids (TS), TDS (total dissolved solids), BOD (biological oxygen demand), and COD (chemical oxygen demand) according to APHA. ${ }^{36)}$ Also, the microbial load in the crude enzyme solutions of both orange and watermelon garbage were monitored weekly.

\subsubsection{Enzymes activity identification analysis in fruit garbage enzymes extract solutions}

The activities of lipase, oxidase, catalase, protease, and amylase in the garbage enzymes of both separate filtrate solutions were determined. The activities of protease, lipase, amylase, catalase, and oxidase were tested by the procedure described in the literature. ${ }^{22,41)}$ The oxidase activity was tested with 2-3 drops of tetra methyl p-phenylenediamine dihydrochloride (TPDDC) on the two filter papers soaked with the two extracts of the garbage enzyme solutions placed on clean slides. For the result of such test, blue colour indicates the presence of oxidase (positive) while absence of oxidase indicated no colour (negative). For the catalase, the extracts of the fruit garbage enzymes solutions were mixed with hydrogen peroxide $\left(\mathrm{H}_{2} \mathrm{O}_{2}\right)$, which catalase decompose it into water $\left(\mathrm{H}_{2} \mathrm{O}\right)$ and oxygen $\left(\mathrm{O}_{2}\right)$. The evolution of gas bubbles indicates the presence of catalase while zero bubbles indicates absence of catalase.

Amylase activity was validated with drops of iodine solution. $1 \%$ of $1.5 \mathrm{~cm}^{3}$ of starch solution was poured into a test tube and labelled A. The solution in the test tube was then mixed with extract solution of the fruit garbage enzymes and mixed thoroughly. Two drops of the mixture of test tube A was spotted on tiles containing the iodine solution and mixed with a glass rod. Colour change of iodine solution from dark blue to brown was observed and recorded as an indication of amylase. The Lipase activity was analyzed by titrimetric method, where $10 \mathrm{~cm}^{3}$ of extract solution of garbage enzymes was added into a conical flask and its $\mathrm{pH}$ was adjusted to 6 using sodium phosphate buffer. $1 \mathrm{~cm}^{3}$ of the Aliquot portion of the $\mathrm{pH}$ adjusted sample was then added to $2.5 \mathrm{~cm}^{3}$ distilled water along with $1 \mathrm{~cm}^{3}$ Tris- $\mathrm{HCl}$ buffer and $3 \mathrm{~cm}^{3}$ Olive oil. The solution was well mixed and incubated at room temperature for 15 mins. After which, $3 \mathrm{~cm}^{3}$ of $95 \%$ ethanol solution and 3 drops of Phenolphthalein indicator were added to the solution and titrated against $\mathrm{NaOH}$ until dark pink colour appeared.

Protease activity was analyzed spectrophotometrically. $5 \mathrm{~cm}^{3}$ of $5 \%$ Gelatin was treated with $3 \mathrm{~cm}^{3}$ of the extract of garbage enzymes and allowed to stand for 15 mins, after which 25 $\mathrm{cm}^{3}$ of $5 \%$ trichloroacetic acid solution was added to stop the 
reaction. $5 \mathrm{~cm}^{3}$ of the supernatant was collected followed by addition of $5 \mathrm{~cm}^{3}$ reagent $\mathrm{C}$ and was allowed to stand for 10 mins before diluted with $0.1 \mathrm{~cm}^{3}$ Folin reagent. This was allowed to stand for 30 minutes, after which the optical absorption of the sample was measured using UV model Spectrulab $23 \mathrm{~A}$ at $620 \mathrm{~nm}$. The protein concentration was deduced from the protein equivalent calibration curve and protease activity was calculated by the relationship below.

Protease activity

$=$ Absorbance at $620 \mathrm{~nm} \times$ proten concentration $\times$ time

\subsection{Amendment of soil with used motor-oil}

For both 5 and $10 \%$ contamination level in the soil, 50 and $100 \mathrm{~g}$ of oil was added to 950 and $900 \mathrm{~g}$ of soil, respectively. The mixtures were thoroughly homogenised and allowed to stand for two weeks in labeled plastic containers. ${ }^{32)}$ The weight equivalent of the used motor-oil was determined by the gravimetric method described by the American Petroleum Institute (API). In the procedure, hydrometer was used to determine directly the specific gravity of the oil, which was also considered as the density of the oil. After the initial determination of the density of the oil, the required and equivalent volumes of 5 and $10 \mathrm{~g}$ of the oil were determined from the ordinary theory of density, which describes that density of a substance is equal to the mass of a substance divided by the volume of the substance. The experimental procedure followed was also in conformity with standard method ASTM D 1298-85. Control samples were also prepared with soil neither contained oil nor enzymes $\left(\mathrm{C}_{0}\right)$ and soils contaminated with 5 and $10 \%$ contamination level with no enzymatic treatment $\left(\mathrm{C}_{5}\right.$ and $\left.\mathrm{C}_{10}\right)$.

\subsection{Biocatalytic remediation of oil-contaminated soil with orange and watermelon garbage enzymes}

The biocatalytic potency of garbage enzymes solutions of both orange and watermelon were tested by administering them to the soils amended with 5 and $10 \%$ oil pollution levels after 14 days of contamination ${ }^{42)}$, which then thoroughly homogenised. The contaminated soils were then treated by adding $100 \mathrm{ml}$ of the required concentrations of fruit garbage enzyme solutions based on the moisture content needed for effective soil remediation. The application of the fruit garbage enzyme solutions was done at 2 days interval for six weeks. The volume of the fruit garbage enzyme solutions and the 2 days interval were chosen to maintain $10 \%$ moisture content and field capacity of the soils that describes the ability of soil to hold moisture or water content and considered to be an ideal for crop growth, which usually takes place within 2-3 days. ${ }^{43)}$

After six weeks, the experimental response was the percentage of oil and grease $(\mathrm{O} \& \mathrm{G})$ removal which was calculated using Equation (1).

$$
\mathrm{O} \& \mathrm{G}(\%)=\frac{\mathrm{Si}-\mathrm{St}}{\mathrm{Si}} \times 100
$$

where $S_{i}$ was the initial concentration of O\&G in ppm, $S_{t}$ was the concentration of $\mathrm{O} \& \mathrm{G}$ in $\mathrm{ppm}$ at a particular biocatalytic remediation time. This was done after oil and grease contents of the oil-contaminated soils at each biocatalytic remediation time were determined based on the standard test method approved by the Department of Sustainable Natural Resources Soil Survey. The oil and grease content was initially calculated using Equation (2).

$$
\text { O\&G }(\mathrm{ppm})=\frac{\mathrm{W} 2-\mathrm{W} 1}{\text { weight of soil sample taken }} \times 10^{6}
$$

where $\mathrm{W}_{1}$ was the weight of empty beaker before putting decanted mixture of O\&G and hexane (solvent), $\mathrm{W}_{2}$ was the weight of the beaker after evaporation of the solvent used.

\subsection{Statistical experimental design matrix and optimization}

To determine the trial concentrations required for appropriate remediation treatment, the D-optimal design of response surface methodology (RSM) with a 2-level categorical factor designed for oil and grease remediation was conducted with the aid of Design Expert 7.0.0. The design matrix was used for both the orange and watermelon garbage enzyme extract solutions. The two factors design of response surface methodology was used to generate a total of 10 experimental plus 3 control samples runs, respectively. The enzyme concentrations were used as a numerical factor and 2 oil pollution levels as categorical factors. The numerical factor was varied between 1 and 10\%. However, the 2 oil pollution levels of 5 and $10 \%$ were used to observe the remediation of oil and grease (Response 1) and serve as a categorical factor. After carrying out each experimental run, the statistical aspects of oil and grease remediation were done. The design matrices were labelled as sample $C_{o}$ represents the control soil sample (neither contaminated nor treated with fruit garbage enzymes), while $\mathrm{C}_{5}$ and $\mathrm{C}_{10}$ represent control samples (contaminated with 5 and $10 \%$ oil contamination levels 
respectively, but left without treatment with fruit garbage enzymes). However, biocatalytic remediation treatments was administered on the oil-contaminated soil samples according to the designed matrices of Design-Expert shown in Table S1 and S2 for orange and watermelon garbage enzymes extract solutions, respectively. The samples contaminated with $5 \%$ oil contamination level were categorised with enzymes treatment matrices of 1, 3, 4, 6 and 9 (whose percentage enzymes concentrations used for the treatments were 5.43, 7.75, 1.0, 10.0 and 1.0, respectively), while for the $10 \%$ oil contamination level were given treatment matrices of $2,5,7$, 8 and 10 (whose percentage enzymes concentrations used for the treatments were $1.0,3.28,6.62,10.0$ and 10.0 , respectively).

\subsubsection{Analysis of variance and fitting of models}

The responses of the D-optimal design of RSM with 2- level categorical factor designed for this work was carried out. The results of the analysis of variance obtained when the quadratic model was used for the analysis of the experimental data are given in Table S3 and S4 for the orange and watermelon garbage enzymes extract solutions, respectively.

\section{Results and discussion}

\subsection{Microbiological and physicochemical characteristics of soil samples}

Table 1 shows the microbiological and physicochemical parameters of the uncontaminated (control) soil and the soils amended with 5 and $10 \%$ oil pollution levels. The $\mathrm{pH}$ value of the control soil was 6.30 , which indicated that the soil was slightly acidic. However, the $\mathrm{pH}$ changed to 5.83 and 5.93 after the soil was amended with 5 and $10 \%$ pollution levels of used motor-oil, respectively. This indicates that the oil contamination decreased the soil $\mathrm{pH}$ to become more acidic thereby increasing toxicity of the soil, but can still support biological systems. ${ }^{44)}$ On the other hand, it can affect fertility and other physical properties of soils. This change of $\mathrm{pH}$ perhaps occurred due to the presence of the hydrocarbons in the used motor-oil that conceivably reacted with the soil salts and minerals and changed the soil alkaline minerals to acidic. A similar scenario was also observed and reported. ${ }^{45}$

The percentage of moisture contents of oil-contaminated soils were almost 3 times less than the moisture content of the uncontaminated soil. The effect may be attributed to the oil coating which surrounds the soil particles and caused a decrease in hydraulic conductivity of the soils. Also, pore space may be trapped by oil contents instead of water particles thereby reducing moisture flow that hardly supports optimum growth and proliferation of microbes. ${ }^{11,46)}$ A similar observation was also reported in the literature. ${ }^{45)}$ Similarly, oil-contaminated soil exhibits low $\mathrm{pH}$ and moisture content. ${ }^{47)}$ Hence, oil contamination causes soil to lose moisture.

The soil porosity was $33.3 \%$, however, amendment of the soil with 5 and $10 \%$ used motor-oil caused the porosity to decrease to $30.1 \%$ and $27.2 \%$ respectively. When soil is contaminated with oil, the organic substances in the oil that are sticky in nature may be a responsible factor that unites tiny aggregates in the soils and thus, slightly reduced the porosity of the soils. Despite dissimilarity in the levels of oil used for contamination, no substantial decrease in the soil bulk density was observed in the soils amended with 5 and $10 \%$ oil contamination levels separately. The reason for such observation is not far from the low density of the used motor-oil, as its density was less than the density of water. It was reported that only oils that are denser than water might reduce and restrict soil permeability. ${ }^{48,49)}$

The results of the oil and grease (O\&G) for the control and

Table 1. Microbiological and physicochemical characteristics of soil samples.

\begin{tabular}{cccc} 
Parameters & Soil sample 1 & Soil sample 2 & 5.93 \\
pH & 6.3 & 5.83 & 2.2 \\
Moisture content (\%) & 6 & 2.4 & 1.44 \\
Bulk density & 1.77 & 3.43 & 27.2 \\
Porosity (\%) & 33.3 & 5.263 & 9.214 \\
Oil \& Grease (\%) & 0 & $7.7 \times 10^{5}$ & $5.9 \times 10^{5}$ \\
TCC (cfu/g) & $8.6 \times 10^{5}$ & 7.93 & 11.47 \\
TOC (\%) & 0.32 & 3.6 & 3.8 \\
\hline Nitrogen (mg/kg) & 2.4 & & \\
\hline
\end{tabular}

Sample 1: Control soil, Sample 2: 5\% oil-contaminated soil, Sample 3: 10\% oil-contaminated soil. 
oil-amended soils are presented in Table 1. An increase in O\&G was observed with the increasing percentage of used motor-oil. The value changed to 5.263 and $9.214 \%$ after the soil was amended with 5 and $10 \%$ oil pollution levels, respectively. These values exceeded the maximum permissible limit set by USEPA $^{50)}$ and therefore, the soils were truly contaminated with used motor-oil.

The results of the soil total organic carbon (TOC) analysis are also presented in Table 1. The soil TOC in the control soils was observed to be $0.32 \%$. The low content of TOC recorded in the control soil demonstrates that the organic carbon content in the soil was originated from biota, such as peat formation with time and microbial biomass. However, the value of TOC was elevated to 7.93 and $11.47 \%$ after the soil was amended with 5 and $10 \%$ contamination levels, respectively. The substantial increase may be caused by presence of petroleum hydrocarbons in the used motor-oil, which presumably contributed to the observed additional carbon content in the soils. A similar result was observed in a similar study conducted in the past ${ }^{47)}$, where soil contaminated with crude oil exhibited high TOC content. It was also reported that the increase in TOC of oil-polluted soil was observed to correspond with the increase in $O \& G$ content. $^{26,51,52)}$

On the aspect of nitrogen contents, it was observed that the nitrogen content of soil increased with increase in oil contamination levels. The nitrogen content of the control soil was $2.4 \mathrm{mg} / \mathrm{kg}(0.24 \%)$, which was lower relative to the contaminated soils whose values were $3.6 \mathrm{mg} / \mathrm{kg}(0.36 \%)$ and $3.8 \mathrm{mg} / \mathrm{kg}(0.38 \%)$ for 5 and $10 \%$ oil pollution levels, respectively. This could be due to inputs arising from the content of mineral elements in the oil. Okonokhua et al. ${ }^{53)}$ reported an increase in carbon and nitrogen contents of spent lubricant oil-contaminated soil compared to control soil. In contrast, a decrease in the amount of nitrogen present in soil contaminated with spent lubricant oil was observed. ${ }^{54)}$ Such observation may be due to carbon mineralisation and hydrocarbon immobilisation resulted from excessive microbial activity using carbon materials as energy sources and its attendant demand for more nitrogen. On the other hand, it could be that nitrogen in the soil was in the form of ammonium $\left(\mathrm{NH}_{4}^{+}\right)$or nitrate $\left(\mathrm{NO}_{3}{ }^{-}\right)$ions and lost due to evaporation.

On the microbiological analysis, the counts of total coliforms in soils amended with 5 and $10 \%$ oil pollution levels in comparison with that of the control soil are presented in
Table 1. The total coliform counts (TCC) were observed to decrease with increase in oil pollution level. In comparison with control soil, it was observed that the count of coliforms in the soil contaminated with 5 and $10 \%$ oil pollution levels decreased by 10.5 and $31.4 \%$ less than the value of the control soil, respectively. This shown that the microbial diversity in soil was remarkably reduced by oil contamination. Labud et al. ${ }^{55)}$ reported that petroleum hydrocarbons inhibited microbial growth and was observed that such negative effects were greatly worsen in the hydrocarbon-based oil-polluted sandy and clay soils. In a similar work, a decline in the overall microbial diversity owing to oil contamination in soil has also been documented. ${ }^{56,57)}$ The decline in richness and phylogenetic diversity may be linked to the disruption of the balanced nutrients cycle, which may be caused by organic carbon-nutrients interaction hindering effective metabolism, growth, and development of living organisms in the soil ecosystem. $^{58)}$

\subsection{Characteristics of fruit garbage enzymes solutions (FGE)}

The biological and physicochemical characteristics of the fruit garbage enzymes solutions sourced from orange and watermelon peels waste are shown in Table 2. From the results, the crude fermented solutions of orange and watermelon garbage were acidic with $\mathrm{pH}$ values of 3.1 and 3.3 , respectively. This indicates that the bulk of carbohydrates in the fruit wastes were successfully converted into volatile acids while organic acids present in the wastes also leached out into fermented solutions. The electrical conductivity (EC) values were 1,490 and $1,410 \mathrm{~ms} / \mathrm{m}$ for the orange and watermelon enzyme solutions, respectively. It is therefore the presence of organic acids in the fruit wastes that accounts for the conductivity of the garbage enzyme solutions. The TDS values of the filtrates were 1,092 and $1,035 \mathrm{mg} / \mathrm{L}$ for the orange and watermelon, respectively. With these values of

Table 2. Physicochemical and biological properties of the fruit garbage enzyme solution.

\begin{tabular}{lcc}
\multicolumn{1}{c}{ Parameter } & Orange & Watermelon \\
$\mathrm{pH}$ & 3.1 & 3.3 \\
$\mathrm{TDS} \mathrm{mg} / \mathrm{L}$ & 1,092 & 1,035 \\
$\mathrm{EC} \mathrm{mS/m}$ & 1,490 & 1,410 \\
$\mathrm{BOD}_{5} \mathrm{mg} / \mathrm{L}$ & 82.7 & 70.1 \\
$\mathrm{COD} \mathrm{mg} / \mathrm{L}$ & 162 & 140 \\
$\mathrm{TCC} \mathrm{cfu} / 100 \mathrm{~cm}^{3}$ & 5 & 4 \\
\hline
\end{tabular}


TDS, it is clear that the microbes present in the molasses quite helped in the degradation of the complex organic matter present in the fruit wastes, which was responsible for the increased dissolved solids in the solutions. On the relationship between TDS and EC, the relation is not applicable when the solution is a multi-compounds solution or wastewater. In a multi-compounds solution, when the salt concentration reaches a certain level, electrical conductivity is no longer directly related to salt concentration. ${ }^{59)}$

The BOD values were recorded as 82.7 and $70.1 \mathrm{mg} / \mathrm{L}$ while the COD was 162 and $140 \mathrm{mg} / \mathrm{L}$ for orange and watermelon, respectively. The value of BOD is normally used to account for the proportion of the organic content of a sample that is biologically-convertible. In this context, it is clear that orange waste was more susceptible to oxidation by the use of oxygen than watermelon garbage. Similarly, the high value of COD recorded in the garbage enzyme solution of orange indicates that more organic materials were oxidised in the orange wastes than in the watermelon garbage. For the TCC, 5 and $4 \mathrm{cfu} / 100$ $\mathrm{cm}^{3}$ were recorded for orange and watermelon garbage enzymes extract solutions, respectively. The presence or detection of this group of bacteria in garbage enzyme solutions is indicative of a carbohydrate-based or rather sugar-based compounds fermentation process in the fruit wastes. All the physico-chemical results obtained in this work are in conformity with the results reported in the literature. ${ }^{16,22)}$

\subsubsection{Identification of enzymes in the fruit garbage extract solutions (FGE)}

The results of enzyme activities analysis in the orange and watermelon FGE are shown in Table 3. Five enzymatic activities were analysed for the two FGE solutions, which covered catalase, amylase, lipase, protease, and oxidase. Oxidase activity was observed to be absent in both FGE solutions, while Amylase activity was only detected in FGE solution made from orange wastes and not found in

Table 3. Identified enzymes in the fruit garbage extract solutions.

\begin{tabular}{ccc} 
& \multicolumn{3}{c}{ Fruit garbage } \\
Enzymes & Orange & Watermelon \\
\cline { 2 - 3 } Catalase & + & + \\
Oxidase & - & - \\
Amylase & + & - \\
Lipase & + & + \\
Protease & + & + \\
\hline
\end{tabular}

watermelon FGE solution. However, the remaining others were tested positive. Catalase and oxidase belong to the oxidoreductase class of enzymes, while amylase, lipase, protease all belong to the hydrolases class of enzymes. The enzymes tested positive here were similarly observed by Selvakumar and Sivashanmugam ${ }^{60)}$, where the activities of catalase, lipase, amylase, and protease were detected from the fermentation of organic solid waste. In the same vein, similar microorganisms were detected and reported responsible for the production and secretion of the observed enzymes. ${ }^{19,61)}$

In enzymatic bioremediation, extracellular enzymes are used that are secreted by microbes and enter the aqueous phase during an aerobic submerged or anaerobic fermentation process. Such enzymes are naturally produced by the microbes in an aqueous phase and can be harvested as biological catalysts to facilitate the conversion of substrates into products by providing favourable conditions that lower the activation energy of a reaction. ${ }^{40)}$ In their mechanism of action, hydrolytic enzymes disrupt major chemical bonds in the toxic molecules that results in the reduction of their toxicity through degradation. ${ }^{40)}$ In this context, the organic pollutants that are commonly found in a large number of oil spills and other oil-based soil contamination can be largely degraded by lipase in support of oxidase, catalase, protease, and amylase. ${ }^{40)}$ The detection of catalase as one of the oxidoreductase classes of enzymes is considered advantageous in this research, since detoxification of toxic organic compounds by various biomass of bacteria and fungi through oxidative coupling is facilitated by the oxidoreductase class of enzymes. The microbes involved in the secretion of such class of enzymes derive energy through energy-yielding biochemical reactions mediated by such enzymes to cleave chemical bonds and to assist the transfer of electrons from a reduced organic substrate (donor) to another chemical compound (acceptor). During such redox reactions, contaminants hosted in either soil and/or water are finally oxidized to harmless compounds. ${ }^{62)}$ The oxidoreductase class of enzymes in the same way play a part in the detoxification of toxic organic contaminants such as phenolic substances that are produced as part of decomposition fragments of lignin in soil environment. ${ }^{44)}$ Therefore, microbial enzymes have been exploited in the decontamination processes for environmental management.

Similarly, researches have shown that lipase is closely related to the degradation of organic pollutants present in the soil. It has been reported that lipase activity was largely responsible for the drastic reduction of total hydrocarbons in 
Table 4. Summary of experimental design matrix for O\&G biodegradation of soil treated with orange garbage enzymes extract solution.

\begin{tabular}{cccc} 
& Factor 1 & Factor 2 & Response \\
\cline { 2 - 3 } Run & Enzyme conc. $(\%)$ & Pollution level\% $(\mathrm{w} / \mathrm{w})$ & O\&G degradation (\%) \\
2 & 5.43 & 5 & 47.05882 \\
3 & 1.00 & 10 & 45.45455 \\
4 & 7.75 & 5 & 47.05882 \\
5 & 1.00 & 5 & 45.09804 \\
6 & 3.28 & 10 & 46.46465 \\
7 & 10.00 & 5 & 54.90196 \\
8 & 6.62 & 10 & 45.45455 \\
9 & 10.00 & 10 & 53.53535 \\
10 & 1.00 & 5 & 47.05882 \\
$C_{0}($ Control) & 10.00 & 10 & 54.54545 \\
$C_{5}($ Control) & - & - & 0 \\
$C_{10}($ Control) & - & 5 & 39.21569 \\
\hline
\end{tabular}

Table 5. Summary of experimental design matrix for O\&G biodegradation of soil treated with watermelon garbage enzymes extract solution.

\begin{tabular}{cccc}
\multirow{2}{*}{ Run } & Factor 1 & Factor 2 & Response \\
\cline { 2 - 3 } 1 & Enzyme conc. $(\%)$ & Pollution level $\%(w / w)$ & O\&G degradation (\%) \\
2 & 5.43 & 5 & 45.09804 \\
3 & 1.00 & 10 & 45.45455 \\
4 & 7.75 & 5 & 47.05882 \\
5 & 1.00 & 5 & 47.05882 \\
6 & 3.28 & 10 & 46.46465 \\
7 & 10.00 & 5 & 54.90196 \\
8 & 6.62 & 10 & 43.43434 \\
9 & 10.00 & 10 & 53.53535 \\
10 & 1.00 & 5 & 47.05882 \\
$C_{0}($ Control) & 10.00 & 10 & 57.57576 \\
$C_{1}$ (Control) & - & - & 0 \\
$C_{2}$ (Control) & - & 5 & 39.21569 \\
\hline
\end{tabular}

soil contaminated with pool of oil ${ }^{63,64)}$ and thus, the presence of lipase in both the FGE solutions can effectively participate in the biocatalytic remediation of the artificially induced-oil contaminated soil. Lipases have been extracted from bacteria $^{65}$, and therefore, this further support the results of the microorganisms identified in the solutions of FGE of both orange and watermelon wastes.

\subsection{Experimental design matrix for biocatalytic removal of oil and grease (O\&G)}

The responses of the optimal design of RMS with 2-level categorical factors of fruit garbage enzymes extract solutions and oil pollution levels designed for this research work and are presented in Table $\mathbf{4}$ and $\mathbf{5}$ for orange and watermelon garbage enzymes, respectively.

It has been reported that oil and grease $(\mathrm{O} \& \mathrm{G})$ is a better index to monitor the extent of hydrocarbon degradation in soils contaminated by used motor-oil contaminated soil due to reduction of C-H bond in the spent or used motor-oil..$^{5)}$ In this context, it is obvious that the biocatalysts and the oil pollution levels affected the responses. The overall $O \& G$ removal by orange garbage enzymes at the end of week six was presented in Table 4. It was observed the reducing efficiency of the oil and grease content increased with time 
Design-Expert( Software

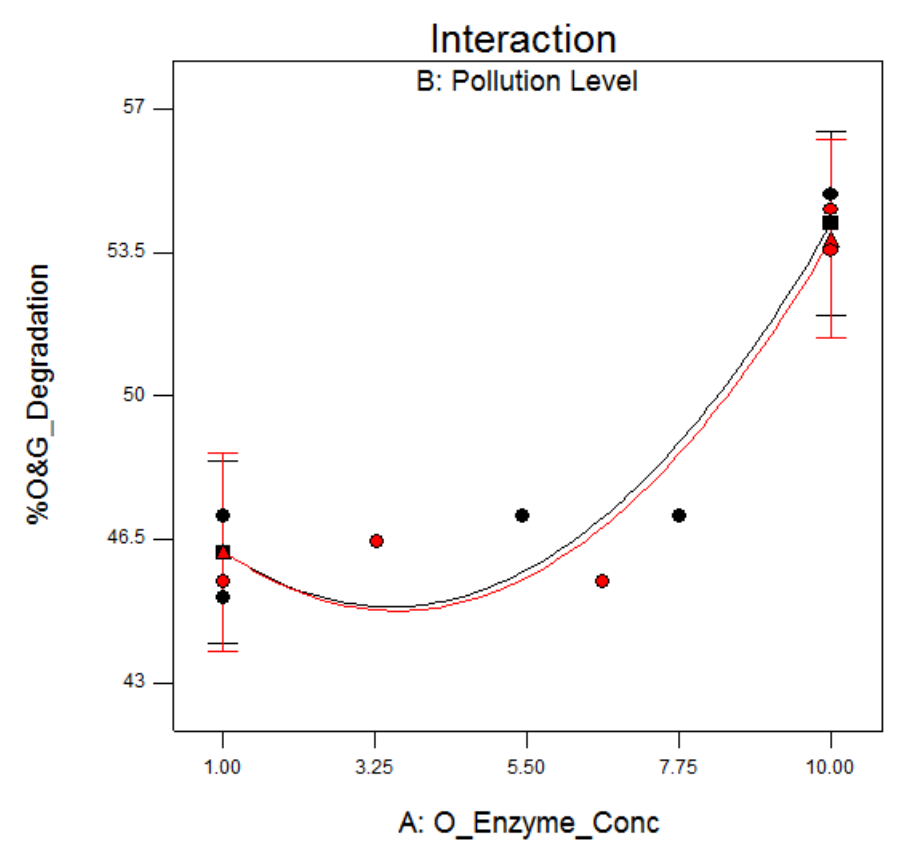

Fig. 1. The effect of orange garbage enzymes extract solution and oil pollution levels of 5 and $10 \%$ on oil and grease removal response.

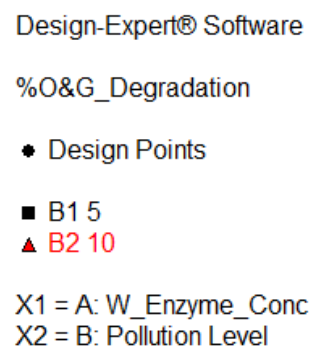

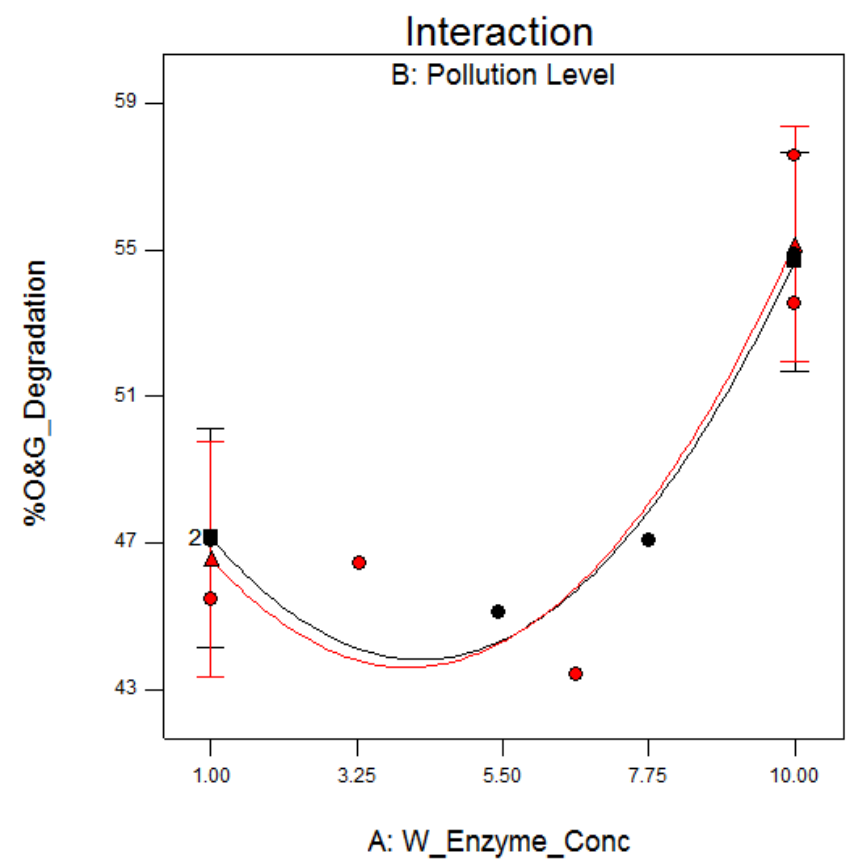

Fig. 2. The effect of watermelon garbage enzymes extract solution and oil pollution levels of 5 and $10 \%$ on oil and grease removal response.

and concentration of the fruit garbage enzymes extracts. As presented in Fig. 1, the process of the biocatalytic removal of oil and grease was characterized by a time factor of a slow decrease in oil concentrations during the early weeks and then followed by a fast activity toward the end of week six. The orange garbage enzymes extract resulted in the maximum biocatalytic remediation of approximately $55 \%$ reduction in oil and grease at both 5 and $10 \%$ oil pollution levels. Interestingly, even with increasing the concentration of orange garbage enzymes to reach $10 \%$, no much difference was observed with increasing oil pollution level from 5 to $10 \%$ (Table 4 and Fig. 1). This indicates that the oil and grease removal efficiency of orange garbage enzymes extract was independent of concentration regardless of oil pollution level. This shows a 
potential advantage of the use of low concentrations of orange garbage enzymes in the remediation of soils contaminated with high oil pollution load, which could be cost-effective.

In contrast, watermelon enzymes extract appeared to show a different trend of oil and grease reduction (Table 5 and Fig. 2). At $10 \%$ watermelon garbage enzymes extract, the maximum reduction of $57.6 \%$ oil and grease was observed. Similarly, at the same enzyme concentration, $54.9 \%$ oil and grease removal efficiency was differently achieved at a $5 \%$ oil contamination level. This implies that when the oil pollution load in the soil increased, the concentration of watermelon enzymes extract also requires to be increased. This observed difference in biocatalytic activity between the two fruit garbage enzymes may be associated with variation in composition of the pool of enzymes in their extract solutions, as indicated in Table 3.

However, the changes of O\&G observed in the control soil samples may be attributed to natural attenuation, which is perhaps accelerated by either or all of the a variety of physical, chemical, or biological processes that acted and reduced the O\&G by $39 \%$. Therefore, soil O\&G can naturally change with time and/or by physicochemical and biological processes. However, the observation made here was perhaps accelerated by all of the volatilization, photolysis and adsorption processes, as the remediation experiments were conducted in an opened-window environment. Accordingly, as natural attenuation is a multi-process line of attack or action upon the oil-contaminated soils, it perhaps responsible for the observed high removal of $O \& G$ in the control soils.

On the other hand, one may argue that the observed activities in the biocatalytic remediation of the oil-contaminated soils were responsible by microbes instead of fruit garbage enzymes. But the microbial population was not enough since the microbial pool was affected by the pollution effect of used motor-oil and thus, the microbial population detected in the oil-contaminated soils was below the minimal value of $1.00 \mathrm{E}+5$ required (see Fig. S1 and S2) for effective biodegradation of oil in soils. ${ }^{50)}$ Therefore, the maximum reduction of oil and grease was largely achieved by the fruit garbage enzymes in six-week time of the remediation process. As a result, this process of remediation could be advantageous, as the adverse factors that affected the microbial population density (which is a major setback factor in bioremediation) could be overcome or mitigated through biotransformation which involved a series of enzymatically catalysed reaction in remediation processes of oil contaminated soils. ${ }^{20,66)}$
Besides, in the treatment of wastewater, it was indicated that lipase was able to remove O\&G in wastewater. Lipases cleave ester bonds of triacylglycerol in O\&G during hydrolysis, thus it has the capacity to liberate all types of acyl chains that assist in reducing the concentration of O\&G and produce short chain volatile fatty acids. ${ }^{67)}$

\subsubsection{Analysis of variance and fitting of models}

After conducting the experiments for 10 runs and 3 controls of the designed matrices, the corresponding responses of the dependent variable oil and grease were statistically analyzed with regards to the designed matrices in Table 4 and $\mathbf{5}$. The statistical analyses of the data of 5 and $10 \%$ pollution levels indicate that the residual values of oil and grease removal by orange and watermelon garbage enzymes in the soil, after the biocatalytic remediation period, ranged from 45.09 to $54.90 \%$ and 45.45 to $54.54 \%$ as well as 45.09 to $54.90 \%$ and 45.45 to $57.57 \%$ at 5 and $10 \%$ pollution levels, respectively (Table 4 and 5). The ten (10) observed experimental responses were used to develop the appropriate models for the dependent response variables. This was made possible because the two independent variables which were orange and watermelon garbage enzymes correlates positively with the one response variable that was oil and grease removal/reduction under the second-order quadratic regression. Therefore, quadratic regression statistical models were developed for orange and watermelon garbage enzymes extract solutions, respectively from the experimental data, as represented by Equation (3) and (4).

For orange garbage enzymes

O\&G (5\% pollution level)

$$
\begin{aligned}
= & +47.4970-1.52067 * \text { O_Enzyme_Conc. } \\
& +0.21917 * \text { O_Enzyme_Conc }{ }^{2}
\end{aligned}
$$

O\&G (10\% pollution level)

$$
\begin{aligned}
= & +47.54971-1.56360 * \text { O_Enzyme_Conc. } \\
& +0.21917 * \text { O_Enzyme_Conc }{ }^{2}
\end{aligned}
$$

For watermelon garbage enzymes

O\&G ( $5 \%$ pollution level)

$$
\begin{aligned}
= & +49.56058-2.72669 * \text { W_Enzyme_Conc. } \\
& +0.32384 * \text { W_Enzyme_Conc }{ }^{2}
\end{aligned}
$$

O\&G (10\% pollution level)

$$
\begin{aligned}
= & +48.85573-2.60802 * \text { W_Enzyme_Conc. } \\
& +0.32384 * \text { W_Enzyme_Conc }{ }^{2}
\end{aligned}
$$


In the above mathematical expression, the terms with positive sign have synergistic effects, while the terms with negative sign have antagonistic effects to the biocatalytic remediation process of oil pollution. Only the significant terms, as indicated in the analysis of variance (Table S3 and S4), were captured in each model. As it has been observed in each of the models, the contributions of the each of the fruit garbage enzymes extract solutions added to the soil are both positive values, implying that the biocatalysts exerted synergistic effects on the biocatalytic remediation process. Also, while the linear and interactive terms exerted synergistic effects on the oil and grease removal, the quadratic terms similarly exerted synergistic effects. However, the quadratic terms exerted greater positive effects (greater coefficients) than the interactive terms (lesser coefficients), implying that the biocatalysts were truly the influential factors in the observed remediation process in the six weeks experimental period. Although both the two fruit garbage enzymes exerted effect, but the linear effects exerted by orange garbage enzymes extract solution on the oil and grease removal in the soil was greater than that exerted by the watermelon enzymes extract solution on the remediation process.

The fitted models for both orange and watermelon garbage enzymes were evaluated by considering the validity of the regression equations and the corresponding coefficients of determination $\left(\mathrm{R}^{2}\right)$, as presented in Table 3 and $\mathbf{4}$, respectively. Statistical significance level is defined by probability value that is less than $0.01(p<0.01)$ or $0.05(p<0.05)$ at 99 or $95 \%$ confidence intervals, respectively. The model F-values of 12.08 and 9.49 imply that the models for oil and grease removal by orange and watermelon garbage enzymes were both significant at $p<0.05$ and $95 \%$ confidence intervals, respectively. Therefore, all the terms in the quadratic regression models are significant with regard to this remediation process.

The lack of fit value in the analysis of variance is employed to indicate whether a particular chosen model is adequately enough to describe a set of experimental data or not. Since the model authenticity increases from linear to quadratic, a typical lack of fit value can be used to verify whether a chosen model is enough in terms of capacity to describe the observed data or a more complicated model would be required. In this case, the lack of fit F-values of 3.01 and 1.28 for the orange and watermelon enzymes models indicate that the lack of fit is not significant relative to the pure error, respectively. The lack of fit not significant means that the chosen model was good and fitted the observed data. Hence, the quadratic regression models chosen for the observed data was quite sufficient in describing the mode of actions of the enzymes (biocatalysts) in the oil-contaminated soils.

Statistical coefficient of determination $\left(\mathrm{R}^{2}\right)$ is a measure of goodness of fit that shows the degree of correlation between observed values and predicted values. The $\mathrm{R}^{2}$ values of 0.9062 for orange garbage enzymes and 0.8836 for watermelon garbage enzymes imply that over $90.62 \%$ and $88.36 \%$ of the variance are attributed to the contributory features of the independent enzymes (biocatalysts) variables to the remediation processes and that the models are highly significant. However, for the orange garbage enzymes model, the predicted $\mathrm{R}^{2}$ of 0.6252 suggests not a very reasonable agreement with the adjusted $R^{2}$ of 0.8313 and the predicted $R^{2}$ of 0.5583 also suggests not a very reasonable agreement with the adjusted $\mathrm{R}^{2}$ of 0.7906 for the watermelon garbage enzymes model. This implies that each model can be used to direct the design space. However, each model provides good fits for the existing data but isn't as good at making predictions. This further confirms that the biocatalytic remediation process needed other externalities such as $\mathrm{pH}$ and temperature, which can affect the enzymatic reaction environment, to be considered. Because, for enzyme catalysed process, it has been established that enzymes work best at optimum $\mathrm{pH}$ and temperature. ${ }^{68)}$

The coefficient of variation $(\mathrm{CV})$ describes a ratio of standard error estimate to the mean of the observed values, which can be used to measure process model reproducibility. A model with $\mathrm{CV}$ less than $10 \%$ is generally considered reproducible. ${ }^{69)}$ Hence, the observed reasonably low co-variance (CV) values of $3.37 \%$ and $4.48 \%$ obtained for the orange and watermelon garbage enzymes models, respectively, signify that the two experiments were conducted with high precision and they can therefore be considered reliable.

\subsubsection{Biocatalysts optimization and models validation}

On the aspect of optimization, to work with optimum reaction parameters is imperatively important when it comes to system or process decision making with reference from pilot to large scale processes. In the application of orange garbage enzymes for biocatalytic remediation oil-contaminated soil, the results of the numerical optimization carried out revealed that at $5 \%$ oil pollution level, the optimum enzymes concentration of $10 \%$ was capable of achieving $54.2 \%$ O\&G removal. On the other hand, when the oil pollution level increased to $10 \%$, the same optimum concentration of $10 \%$ was only capable of 
achieving 53.8\% O\&G removal in six weeks biocatalytic remediation period. However, the result distinguishably revealed that 54.7 and $55.2 \%$ O\&G removal was achieved with optimum $10 \%$ concentration of watermelon garbage enzymes at 5 and $10 \%$ oil pollution level, respectively in the same remediation period.

\section{Conclusion}

This research work has investigated the use of D-optimal RSM design with one categorical factor at two level to find the optimum orange and watermelon garbage enzymes concentrations for the biocatalytic remediation of used motor-oil contaminated soils at two different pollution levels. From the results obtained, it is obvious that the use of D-optimum RSM has proven to be a reliable and powerful tool for modelling and optimization of used motor-oil contaminated soils through biocatalytic remediation strategy. Considerable removal of oil and grease $(O \& G)$ of the soil contaminated by used motor-oil were achieved through biocatalytic remediation with orange and watermelon garbage enzymes extract solution acting as independent biocatalysts variables to the remediation process. Maximum oil and grease $(\mathrm{O} \& \mathrm{G})$ reduction of 54.2 and 53.8 from the oil-contaminated soil at corresponding 5 and $10 \%$ oil pollution levels respectively were observed following the application of $10 \%$ optimum concentration of orange garbage enzymes extract solution. Correspondingly, 54.7 and $55.2 \%$ O\&G removal was achieved with optimum $10 \%$ concentration of watermelon garbage enzymes at 5 and $10 \%$ oil pollution level, respectively after the six weeks remediation period. Reliable predictive quadratic regression models for the dependent response (oil and grease removal) were found to be highly significant. The results indicate that biocatalytic remediation of used motor-oil contaminated soil with the used of orange and watermelon garbage enzymes extract solutions, as biocatalytic agents led to reduction of oil and grease of the used motor-oil contaminated soil within six weeks remediation period. However, in the future, it is important to integrate the combined effects of $\mathrm{pH}$ and temperature so as to ensure that their threshold values required for seamless biocatalytic remediation process to take place is fulfilled. This really worth investigating, particularly for a long-term plan for ecological recovery and restoration. The analysis of variance (ANOVA) revealed that the quadratic model best represented the biocatalytic remediating system for $\mathrm{O} \& \mathrm{G}$ removal in oil-contaminated soil.

\section{Acknowledgments}

The authors wish to thank the technologists of both Soil and Sanitary and Public Health laboratories of the Department of Civil Engineering of Abubakar Tafawa Balewa University, Bauchi, Nigeria for their experimental technical supports. Similar appreciation also goes to the team of technologies in the Department of Applied Microbiology of the same institution for their technical support during the microbiological assessments and fruit garbage (orange and watermelon peels waste) enzymes identifications of all the experimental samples.

\section{References}

1. O. O. P. Faboye, Industrial pollution and waste management, Dimensions of Environmental Problems in Nigeria, O, Akinjide (Eds), Friedrich Ebert Foundation, Washington D. C, pp. 12-25(1997).

2. C. C. Osubor, G. O. Anoliefo, Inhibitory effect of spent lubrication oil on the growth and respiratory function of Arachis hypogea L, Benin Sci. Dig., 1, 73-79(2003).

3. U. U. Ifeanyi, P. O. Agwu, The effect of spent engine oil discharge on soil properties in an automobile mechanic village in Nekede, Imo State, Nigeria, IOSR J. Environ. Sci. Toxicol. Food Technol., 8, 28-32(2014).

4. J. D. Udonne, H. O. Onwuma, A study of the effects of waste lubricating oil on the physical/chemical properties of soil and the possible remedies, J. Petrol. Gas Eng., 5(1), 9-14(2014).

5. S. Abdulsalam, S. S. Adefia, I. M. Bugaje, S. Ibrahim, Bioremediation of soil contaminated with used motor oil in a closed system, J. Bioremediat. Biodegrad., 3(12), 3-9(2012).

6. J. Pichtel, Oil and gas production wastewater: Soil contamination and pollution prevention, Appl. Environ. Soil Sci., 2016(2016).

7. A. Romanus, A. Omolola, S. Patrick, O'kwu, G. Ifeoma, Bacterial degradation of petroleum hydrocarbons in crude oil polluted soil amended with cassava peels, Am. J. Res. Commun., 3(7), 99-118(2015).

8. J. C. Ssempebwa, D. O. Carpenter, The generation, use and disposal of waste crankcase oil in developing countries: A case for Kampala district, Uganda, J. Hazard. Mater., 161(2-3), 835-41(2009).

9. J. L. A. Filho, L. G. M. Moura, A. C. S. Ramos, Liquid extraction and adsorption on solid surfaces applied to use lubricant oils recovery, Braz. J. Chem. Eng., 27, 687-697 (2010).

10. M. Chorom, H. S. Sharifi, H. Motamedi, Bioremediation of a crude oil-polluted soil by application of fertilizers, J. Environ. Health Sci. Eng., 7, 319-326(2010).

11. G. O. Adams, P. T. Fufeyin, S. E. Okoro, I. Ehinomen, 
Bioremediation, biostimulation and bioaugmentation: A review, Int. J. Environ. Bioremediat. Biodegrad., 3, 28-39 (2015).

12. K. Demnerová, M. Mackova, V. Speváková, K. Beranova, L. Kochánková, P. Lovecká, E. Ryslavá, T. Macek, Two approaches to biological decontamination of groundwater and soil polluted by aromatics - characterization of microbial populations, Int. J. Microbiol., 8(3), 205-211(2005).

13. M. Pala, D. De Carvalho, J. C. Pinto, G. L. Sant'Anna Jr, A suitable model to describe bioremediation of a petroleum-contaminated soil, J. Int Bioremediat. Biodegrad., 58(3-4), 254-260(2006).

14. M. Xia, R. Chakraborty, N. Terry, R. P. Singh, D. Fu, Promotion of saltgrass growth in a saline petroleum hydrocarbons contaminated soil using a plant growth promoting bacterial consortium, Int. Biodeterior. Biodegrad., 146, 104808(2020).

15. T. P. Ruggaber, J. W. Talley, Enhancing bioremediation with enzymatic processes: a review, J. Hazard. Toxic Radioact. Waste Manag., 10(2), 73-85(2006).

16. F. Nazim, V. Meera, Treatment of synthetic greywater using $5 \%$ and $10 \%$ garbage enzyme solution, Bonfring Int. J. Ind. Eng. Manag. Sci., 3(4), 111-7(2013).

17. H. J. Roman, J. E. Burgess, B. I. Pletschke, Enzyme treatment to decrease solids and improved digestion of primary sewage sludge, African J. Biotechnol., 5(10), 963-967(2006).

18. A. Ayol, S. K. Dentel, Enzymatic treatment effects on dewaterability of anaerobically digested biosolids-II: laboratory characterizations of drainability and filterability, Process Biochem., 40(7), 2435-42(2005).

19. R. Singh, M. Kumar, A. Mittal, P. K. Mehta, Microbial enzymes: industrial progress in 21st century, 3 Biotech, 6(2), 1-5(2016).

20. S. K. Ahuja, G. M. Ferreira, A. R. Moreira, Utilization of enzymes for environmental applications, Crit. Rev. Biotechnol., 24(2-3), 125-54(2004).

21. N. Abd-Aziz, B. C. Tan, N. A. Rejab, R. Y. Othman, N. Khalid, A new plant expression system for producing pharmaceutical proteins, Mol. Biotechnol., 62(4), 240-51(2020).

22. C. Arun, P. Sivashanmugam, Investigation of biocatalytic potential of garbage enzyme and its influence on stabilization of industrial waste activated sludge, Process Saf. Environ. Prot., 94, 471-478(2015).

23. B. Prakash, How to make and use garbage enzyme, http://www.ecowalkthetalk.com, June(2020).

24. S. Bhargava, K. S. Wenger, M. R. Marten, Pulsed addition of limiting carbon during Aspergillus oryzae fermentation leads to improved productivity of a recombinant enzyme, Biotechnol. Bioeng., 82(1), 111-117(2003).

25. P. S. J. Cheetham, The applications of enzymes in industry, In Handbook of enzyme biotechnology, 2nd ed., A. Wiseman, Ellis Horwood Limited, London, UK(1985).

26. S. O. Giwa, K. A. Abdulyekeen, A. Giwa, I. Misau, Optimization of used motor oil contaminated soil biostimulation process, in Proceedings of the 2nd International Engineering Conference, School of Engineering and
Engineering Technology Federal University of Technology, Minna, pp. 164-171(2017).

27. S. Giwa, A. Giwa, K. Zeybek, H. Hapoglu, Electrocoagulation treatment of petroleum refinery wastewater: optimization through RSM, Int. J. Eng. Res. Technol., 2(8), 606-614(2013).

28. M. Munawar, P. Sasongko, D. Kusuma, Optimization of nutrient supplement in hydrocarbon bioremediation process with biostimulation techniques in coastal regions, Int. J. Recent Development Eng. Technol., 3(4), 77-83(2014).

29. T. M. Obuotor, A. O. Sakariyau, B. S. Bada, Enhanced biodegradation of spent engine oil contaminated soil using organic wastes, Appl. Environ. Res., 38(3), 27-38(2016).

30. R. U. Ofoegbu, Y. O. Momoh, I. L. Nwaogazie, Bioremediation of crude oil contaminated soil using organic and inorganic fertilizers, J. Petroleum Environ. Biotechnol., 6(1), 1-6(2015).

31. S. Yan, Q. Wang, L. Qu, C. Li, Characterization of oil-degrading bacteria from oil-contaminated soil and activity of their enzymes, Biotechnol. Biotechnol. Equip., 27(4), 3932-3938(2013).

32. S. E. Agarry, K. M. Oghenejoboh, Enhanced aerobic biodegradation of naphthalene in soil: kinetic modelling and half-life study, Int. J. Environ. Bioremediat. Biodegrad., 3(2), 48-53(2015).

33. A. Walkley, I. A. Black, An examination of the Degtjareff method for determining soil organic matter, and a proposed modification of the chromic acid titration method, Soil Sci., 37(1), 29-38(1934).

34. M. R. Motsara, R. N. Roy, Guide to laboratory establishment for plant nutrient analysis, Food and Agriculture Organization, Rome, Italy(2008).

35. S. S. Staff, Keys to Soil Taxonomy, in Proceedings of 12th ed. Natural Resources Conservation Service, United States Department of Agriculture, Jeju, Korea(2014).

36. American Public Health Association, Standard methods for the examination of water $\&$ wastewater, 21st ed., American Public Health Association, Washington, D.C., USA(2005).

37. S. Agarry, G. K. Latinwo, Biodegradation of diesel oil in soil and its enhancement by application of bioventing and amendment with brewery waste effluents as biostimulationbioaugmentation agents, J. Ecol. Eng., 16(2), 82-91(2015).

38. L. O. Odokuma, G. C. Okpokwasili, Seasonal ecology of hydrocarbon-utilizing microbes in the surface waters of a river, Environ. Monit. Assess., 27(3), 175-191(1993).

39. S. C. Onuoha, E. I. Chukwura, K. Fatokun, Stimulated biodegradation of spent lubricating motor oil in soil amended with animal droppings, Am. J. Biosci., 2(1), 19-27(2014).

40. C. S. Karigar, S. S. Rao, Role of microbial enzymes in the bioremediation of pollutants: a review, Enzyme Res., 2011 (2011).

41. M. Cheesbrough, District laboratory practice in tropical countries, 1,2nd ed., Cambridge University Press, England, UK, pp. 135-162(2005).

42. K. Ramadass, M. Megharaj, K. Venkateswarlu, R. Naidu, Ecological implications of motor oil pollution: earthworm survival and soil health, Soil Biol. Biochem., 85, 72-81(2015). 
43. R. K. Rai, V. P. Singh, A. Upadhyay, Planning and evaluation of irrigation projects: methods and implementation, Academic Press, Cambridge, USA, pp. 505-523(2017).

44. M. Vidali, Bioremediation. An overview, Pure Appl. Chem., 73(7), 1163-1172(2001).

45. Devatha C. P, A. V. Vishal, J. P. Rao, Investigation of physical and chemical characteristics on soil due to crude oil contamination and its remediation, Appl. Water Sci., 9(4), 1-10(2019).

46. E. O. Fenibo, G. N. Ijoma, R. Selvarajan, C. B. Chikere Microbial surfactants: The next generation multifunctional biomolecules for applications in the petroleum industry and its associated environmental remediation, Microorganisms, 7(11), 581(2019).

47. K. R. Singh, A. N. Sharma, S. U. Chandra, Comparative analysis of physico-chemical parameters of soil contaminated with petroleum hydrocarbons collected from semi-arid (Jaipur-Ajmer) and arid (Barmer) regions of Rajasthan with reference to Bioremediation, J. Phytol. Res., 30(2), 89-99 (2017).

48. N. Brady, R. W. Ray, The Nature and Properties of Soil, 14th ed., NJ: Prentice Hall, New Jersey, USA(2008).

49. E. E. Abosede, Effect of crude oil pollution on some soil physical properties, J. Agric. Vet. Sci., 6(3), 14-17(2013).

50. S. Abdulsalam, I. M. Bugaje, S. S. Adefila, S. Ibrahim, Comparison of biostimulation and bioaugmentation for remediation of soil contaminated with spent motor oil, Int. J. Environ. Sci. Technol., 8(1), 187-194(2011).

51. J. C. Okolo, E. N. Amadi, C. T. I. Odu, Effects of soil treatments containing poultry manure on crude oil degradation in sandy loam soil, Appl. Biol. Environ. Res., 3(1), 47-53(2005).

52. E. J. Umana, P. I. Akwaji, A. A. Markson, Bioremediation of spent engine oil contaminated soil by using fungus, Penicillium sp., Int. Lett. Nat. Sci., 59(2016).

53. B. O. Okonokhua, B. Ikhajiagbe, G. O. Anoliefo, T. O. Emede, The effects of spent engine oil on soil properties and growth of maize (Zea mays L.), J. Appl. Sci. Environ. Manag., 11(3), 147-152(2007).

54. J. Kayode, A. A. Oyedeji, O. Olowoyo, Evaluation of the effects of pollution with spent lubricating oil on the physical and chemical properties of soil, Pac. J. Sci Technol., 10(1), 387-390(2009).

55. V. Labud, C. Garcia, T. Hernandez, Effect of hydrocarbon pollution on the microbial properties of a sandy and a clay soil, Chemosphere, 66(10), 1863-1871(2007).

56. S. J. Varjani, Microbial degradation of petroleum hydrocarbons, Bioresour. Technol., 223, 277-286(2017).

57. S. Mnif, S. Sayadi, M. Chamkha, Biodegradative potential and characterization of a novel aromatic-degrading bacterium isolated from a geothermal oil field under saline and thermophilic conditions, Int. Biodeter. Biodegrad., 86, 258-264(2014).
58. J. van Dorst, S. D. Siciliano, T. Winsley, I. Snape, B. C. Ferrari, Bacterial targets as potential indicators of diesel fuel toxicity in subantarctic soils, Appl. Environ. microbiol., 80(13), 4021-4033(2014).

59. J. U. Iyasele, D. J. Idiata, Investigation of the relationship between electrical conductivity and total dissolved solids for mono-valent, di-valent and tri-valent metal compounds, Int. J. Eng. Res. Rev., 3(1), 40-48(2015).

60. P. Selvakumar, P. Sivashanmugam, Multi-hydrolytic biocatalyst from organic solid waste and its application in municipal waste activated sludge pre-treatment towards energy recovery, Process Saf. Environ. Prot., 117, 1-10(2018).

61. P. Perucci, Enzyme activity and microbial biomass in a field soil amended with municipal refuse, Biol. Fertil. Soils, 14(1), 54-60(1992).

62. F. Mohsenzadeh, A. C. Rad, M. Akbari, Evaluation of oil removal efficiency and enzymatic activity in some fungal strains for bioremediation of petroleum-polluted soils, Iranian J. Environ. Health Sci. Eng., 9(1), 1-8(2012).

63. R. Margesin, A. Zimmerbauer, F. Schinner, Soil lipase activity - a useful indicator of oil biodegradation, Biotechnol. Tech., 13(12), 859-863(1999).

64. R. Riffaldi, R. Levi-Minzi, R. Cardelli, S. Palumbo, A Saviozzi, Soil biological activities in monitoring the bioremediation of diesel oil-contaminated soil, Water Air Soil Pollut., 170(1), 3-15(2006).

65. M. P. Prasad, K. Manjunath, Comparative study on biodegradation of lipid-rich wastewater using lipase producing bacterial species, Indian J. Biotechnol., 10, 121-124(2011).

66. I. C. Ossai, A. Ahmed, A. Hassan, F. S. Hamid, Remediation of soil and water contaminated with petroleum hydrocarbon: A review, Environ. Technol. Innov., 17, 100526(2020).

67. J. Jeganathan, A. Bassi, G. Nakhla, Pre-treatment of high oil and grease pet food industrial wastewaters using immobilized lipase hydrolyzation, J. Hazard. Mater., 137(1), 121-128(2006).

68. S. Sanchez, A. L. Demain, Useful microbial enzymes - an introduction, Biotechnology of microbial enzymes, Academic Press, Cambridge, USA, pp. 1-11(2017).

69. A. Zeileis, Econometric computing with $\mathrm{HC}$ and HAC covariance matrix estimators, J. Stat. Softw., 11(10), $1-17(2004)$.

\section{Declaration of Competing Interest}

The authors declare that they have no known competing financial interests or personal relationships that could have appeared to influence the work reported in this paper. 


\section{Authors and Contribution Statement}

\section{Indo Sabo Bulai}

Department of Environmental Management Technology, Abubakar Tafawa Balewa University, MSc Student, ORCID (C) 0000-0003-2153 -6106: Data curation, Methodology, Project administration, Visualization, Writing - review and editing, Resources, Supervision.

\section{Haruna Adamu}

Department of Environmental Management Technology, Abubakar Tafawa Balewa University, $\mathrm{PhD}$, ORCiD (1) 0000-0002-1899-8281: Data curation, Data analysis, Methodology, Project administration, Investigation, Visualization, Writing - original draft, Supervision, Validation, Funding acquisition.

\section{Yuguda Abubakar Umar}

Department of Environmental Management Technology, Abubakar Tafawa Balewa University, PhD, ORCiD 이 0000-0003-4553-1959: Data analysis, Visualization, Writing - original draft, Supervision.

\section{Ahmed Sabo}

Department of Environmental Management Technology, Abubakar Tafawa Balewa University, Professor, ORCiD(이 0000-0001-9814

-4691: Project administration, Investigation, Visualization, Supervision, Validation. 